\title{
How Profound Changes in Stakeholder Relations Allowed an SME to Enter and Gain a Foothold in a Highly Competitive Sector?
}

\author{
Michel Barabel ${ }^{1}$ \& Olivier Meier ${ }^{1}$ \\ ${ }^{1}$ University Paris Est IRG, France \\ Correspondence: Olivier Meier, University Paris Est IRG, Campus Sénart Avenue Pierre Point 77127 Lieusaint, \\ France. Tel: 33-1-6413-4481. E-mail: meier@u-pec.fr
}

Received: October 21, 2011 Accepted: April 30, 2012 Online Published: July 1, 2012

doi: 10.5539/ibr.v5n7p84 URL: http://dx.doi.org/10.5539/ibr.v5n7p84

\begin{abstract}
This article examines the relationship between strategy and CSR in small businesses. In particular, it aims to show how CSR, far from merely being a series of constrictions, can under certain conditions provide SMEs with an opportunity to make their mark in a given sector. According to this view, CSR can offer companies with limited resources a chance to overturn key structural factors by facilitating new modes of interaction and organisation in the development of their activities.
\end{abstract}

Keywords: CSR, management, strategic innovation, proximity, SME, shareholder strategy

\section{Introduction}

The majority of studies dealing with Corporate Social Responsibility (CSR) initially focused on large companies, and these were consequently held up as the norm in terms of CSR. This approach views CSR as a method exploited by major companies to further extend their competitive edge. However, a number of recent studies have challenged these assumptions about a positive correlation between the social and societal performance of a company and its size, and have concentrated instead on the advantages of small and medium-sized businesses with regard to CSR. Using the case of a company in the food sector, we analyse the conditions and mechanisms favourable to such relations, in which CSR, far from being an array of constrictive shackles for small companies, can in fact constitute a creative source of value by modifying the cornerstones of competition.

\section{Impact of Company Size on CSR Strategy}

2.1 CSR Viewed as the Institutionalisation of New Environmental Constraints and Norms Favourable to Large Companies

The notion of corporate social responsibility (CSR) is a central topic in current management research (Wood, 1991; Jones, 1995; Carroll, 1999; De Bakker, Groenewegen \& Den Hond, 2005; Capron \& Quairel-Lanoizelée, 2007; Brabet, 2009).

Although many definitions of the term exist, we shall define CSR as “a concept whereby companies integrate social and environmental concerns in their business operations and in their interaction with their stakeholders on a voluntary basis” (European Commission, 2007).

The emergence and development of the concept of CSR have been commonly linked in the literature to the theme of legitimacy (Martinet \& Reyraud, 2004) as it affects companies over the last two decades. This resulted in the gradual introduction of a new institutionalised environment (Gabriel, 2007; Valiorgue, 2005) placing pressure on companies to incorporate in their own strategic and managerial planning increased awareness of ecological, social and societal issues and their consequences (Reynaud, 2006). One outcome of this is the creation of a number of tools and principles such as codes of good practice, value charters, diversity management, norms/labels, partnerships with NGOs, quality standards (e.g. ISO 14 000), CSR reports / GRI reporting, and so on, the majority of which emerged within major multinational companies (Jenkins, 2006). In this sense, the concept of CSR led to a change of perspective in companies regarding their environment, moving from a shareholder-based approach as advocated by authors such as Friedman (1970) towards catering to the expectations of a wide range of stakeholders (Wood, 1991; Caroll, 1999). In particular, these new pressures created institutional isomorphism (Di Maggio \& Powell, 1991), with companies being obliged to institute CSR policy under pain of sanction by the various stakeholders. In this respect, some authors feel that CSR now 
constitutes a necessary first step towards obtaining a "licence to operate” within a given market (Graafland et al., 2003).

Initially, most studies of Corporate Social Responsibility (CSR) concerned major companies, which consequently became the norm in CSR (Hoivik \& Shankar, 2010; Blombäck \& Wigren, 2009; Jenkins, 2004; Massey, 2003; Southwell, 2004). Naturally, these studies suggest that large companies are the best equipped to respond to the requirements of CSR in terms of organisation, thanks to their extensive financial and human resources (Graafland et al., 2003; Castka et al., 2004; Husted \& Allen, 2007; etc.), their ability to mobilise an array of different professional skills, and their legal know-how (Lepoutre \& Heene, 2006). They emphasise how globalisation and the acceleration of scientific and technological change force companies to innovate ever more rapidly. This need for innovation favours large companies able to allocate extensive resources to continuous change, thereby reinforcing the competitive advantages of companies already in existence. Large companies thus appeared to constitute the reference organisational model, and the most capable of facing up to these new environmental constraints (Blombäck \& Wigren, 2009), since a company of this size "will make relatively more use of formal and public instruments to communicate its responsibility and to build up a consistent business culture, whereas small firms use more informal means” (Graafland et al., 2003).

According to this viewpoint, CSR may be interpreted as a means employed by large companies to increase their competitive edge, either directly by insisting on the use of standard practices (DiMaggio \& Powell, 1983), or indirectly by strengthening the requirement of justified structures (Meyer \& Sott, 1986). In this regard, most of the tools used in CSR have in fact been designed by multinationals and have subsequently been forced on SMEs. This approach supports the notion that greater size is advantageous as regards the changes imposed by CSR.

\subsection{Strategic Innovation and CSR: An Alternative Approach for Small Businesses?}

A number of studies have challenged the notion of a positive correlation between a company's competitiveness and its size, emphasising the advantages of small and medium-sized enterprises (Foray \& Mowery, 1988; Guerci, 1990). According to these authors, SMEs are in fact more flexible organisations able to adapt rapidly to the changing circumstances of supply and demand (Dogson \& Rothwell, 1991). This new approach rejects a conformist vision of strategy, consisting of a desire to comply with environmental characteristics (Di Maggio \& Powell, 1983; Christensen et al., 2002; Baretto \& Baden-Fuller, 2006), stressing instead the need for a new vision of the future based upon a more pro-active approach.

These studies have found an echo in the manner in which companies seek to approach and manage CSR. Recent studies in fact tend to view CSR not simply as a difficult requirement to meet (Perry \& Towers, 2009) but rather as an opportunity for value creation that allows small and medium-sized companies to enter markets (Husted \& Allen, 2007; Hoivik \& Shankar, 2011) through the creation of new business models (Jenkins, 2009; Moore \& Manring, 2009; Seuring \& Muller, 2008).

According to this way of thinking, despite their limited resources, small and medium-sized companies can adopt policies of voluntary transformation of their environment, overturning the key factors and parameters for success or simply creating new rules. Existing studies identify two distinct approaches to CSR among SMEs (Table 1):

- the dominant approach, in which CSR is viewed by SMEs as a constraint and a further difficulty to be overcome, in some cases engendering hostility, avoidance or conformity (diktat and leadership imposed by multinationals);

- a more recent and as yet minority approach, in which CSR is seen as an opportunity able to generate innovation and create value, with SMEs adopting a proactive strategy and pressing home their natural advantages (adaptability, flexibility, proximity, close relationship with customers).

Table 1. Attitudes of the various actors to CSR

\begin{tabular}{|c|c|c|c|c|}
\hline Attitudes of actors to CSR & \multicolumn{3}{|c|}{ Traditional model (large company domination) } & Strategic innovation model \\
\hline SMEs & $\begin{array}{l}\text { Resistance } \\
\text { (opposition) }\end{array}$ & $\begin{array}{l}\text { Passive } \\
\text { (inaction) }\end{array}$ & $\begin{array}{l}\text { Defensive /Imitation } \\
\text { (do little, do gradually, } \\
\text { do as little as possible, } \\
\text { do afterwards) }\end{array}$ & \multirow{2}{*}{$\begin{array}{l}\text { Proactive (take advantage of the new } \\
\text { competitive context created by CSR to } \\
\text { enter a new market and strengthen one's } \\
\text { position through innovation) } \\
\text { Adoption of a traditional strategy } \\
\text { (adaptation) that allows SMEs room for } \\
\text { manoeuvre. }\end{array}$} \\
\hline Large companies & \multicolumn{3}{|c|}{$\begin{array}{l}\text { Greater resources and available skills allow manipulation of } \\
\text { CSR as a new barrier to entry or an additional constraint. }\end{array}$} & \\
\hline
\end{tabular}




\subsection{Core Issue of the Study}

The aim of this article is to analyse the way in which the company Michel et Augustin, despite limited resources, has managed to change the rules of the competitive game to its advantage within the biscuit sector, despite the size and weight of powerful competitors. In particular, we will show how the company has used CSR to transform its relations with its various stakeholders, thereby altering the nature of its activities. The case we present here illustrates the minority approach adopted by SMEs to CSR, and our article seeks to provide an understanding of the stakes and mechanisms involved.

\section{Study Methods}

\subsection{Data Collection Methods}

Our analysis of the terrain focused on the CSR strategy of a small innovative company in the food sector in its bid to compete with more powerful rival companies. Although the use of a single case may be debated, the choice of a single terrain is justifiable because of its critical nature (Koenig, 2005). Further, our decision was greatly influenced by the opportunity we were afforded to study this case in depth with unrestricted access to a large amount of information otherwise not readily consultable by scientific researchers (contact with directors, visits to the company site, discussion with consumers, exchange of views with the company's partners, interviews with journalists). It is thus not our intention here to present a universal development strategy applicable to all companies within the given sector, but rather to uncover and understand the mechanisms at work and to explain them in the light of new theories and specific interpretational approaches.

Our method involves the construction of a case of innovative strategy within the food sector, based upon a novel and personalised interpretation of CSR as means of forging new types of relationships with stakeholders. The case has been constructed from primary and secondary data in accordance with the principles set out by Yin (2003), namely: multiple sources, creation of a database built on cases, and collection of data determined by the research issue.

Our analysis is based on a multisource approach combining primary and secondary data (Frankfort-Nachmias et al., 1992; Stewart, 1984) obtained from various company stakeholders (employees, clients, journalists, specialised shops and major retailers). This approach enabled us to track the company's development, establish links between events, follow the key stages of the process, and better understand direct and indirect effects, all within a realistic and identifiable timeframe (Smith et al., 1992). Our analysis draws upon face-to-face interviews (Yeung, 1995; Seale, 1999) with the company's founders and staff and (20\% of its employees), as well as a number of actors within the environment (journalists and food sector specialists), and upon scrutiny of different media:

- some 15 articles from financial newspapers (Note 1);

- a dozen TV programmes (Télématin France 2, M6 100\% mag, E=M6, Capital M6, Kezeco TV, Business Direct 8, BFM TV, France 3 JT, TF1 Attention à la marche, etc.);

- several radio broadcasts (France Inter, Europe 1, Radio Classique, BFM, NRJ, etc.).

The questions asked were open, allowing new themes to merge and providing the possibility of establishing new relationships between the various items (Wilkinson \& Young, 2004). Our interviews began with questions about the creation of the company, its key aims and principles, and moved on to questions concerning the growth strategy adopted and the development of strategies for the coming years.

We were able also able to collect a certain number of documents published by the company on its website (press releases, dossiers, studies). Similarly, we collected information from the company's customers in two ways: by lexical analysis of messages left on the company's Facebook page (investigation of 18 messages posted daily over a one-month period, i.e. 554 posts analysed in all - Note 2) and of informal exchanges with consumers (face-to-face validation of some 30 customers) at the company's head office during two of its monthly open-door events (on the first Thursday of each month).

Case selection was based on three criteria:

- the company's strategic aims and its chosen method of development within a highly competitive sector characterised by the presence of extremely powerful actors;

- the company's innovative characteristics and the manner in which CSR is used by the company in order to ensure competitiveness within the sector; 
- the results obtained, which demonstrate exceptional success based on new directions far removed from the classic requirements of market share, size and resource mobilisation.

\subsection{Data Processing Methods}

Regarding data processing, for the face-to-face interviews, we used a system involving initial data organisation (Miles \& Huberman, 2003), after which we reviewed the initial data to assess relevance, in other words to determine how this data was confirmed, modified or contradictory. On reviewing the data, we resumed qualification and the repetitive process was continued until plausible and reliable organisation was achieved, resulting in an intelligible discourse and saturation of the various codified meanings (Pourtois \& Desmet, 1997; Karsenti \& Savoie-Zajc, 2000).

Customer posts on the company's Facebook page underwent qualitative content analysis. We decided to code all data to obtain an overall vision by individual theme focusing on the nature of relations between Michel et Augustin and its customers as expressed by the actors themselves (Ryan \& Bernard, 2003; Andrew et al., 2008).

To this end, we use the following approach:

- reading of customer comments in relation to the central issue;

- formulation of the aims of analysis: identification of elements relating to the concept of stakeholders and customer/company relations;

- open coding (description of ideas being sought and related words);

- classification by theme;

- hierarchical organisation of words and themes by frequency using the Nvivo 9 data processing software package (QSR International, Cambridge, MA);

formalisation of interpretations.

\section{Case Study of Michel et Augustin}

This section presents the impact of CSR on the biscuit sector and on the strategy of actors within the sector, in particular Michel et Augustin.

\subsection{Specific Features of the Biscuit Market before and after Institutionalisation of the Principles of CSR}

The biscuit market forms part of the food sector. In 2005, this market was worth around $€ 1.35$ bn and was dominated by two multinational firms, Lu (Groupe Danone) and United Biscuits (BN, Delacre), with respective market share of $40.7 \%$ and $11.3 \%$.

The market is characterised by declining sales (-2\% in 2004 and in 2005) and increasingly powerful distributor brands (MDD) with a market share of some $24.8 \%$ in terms of value and $35.6 \%$ in terms of volume $(+3 \%$ over 2004). Other well-known brands are also present in this market, such as Bahlsen St Michel (4.8\% market share in terms of value), Andros, Masterfoods, Cadbury (Fingers), etc.

Like the rest of the food sector, the biscuits market has been characterised since the early 2000s by increased concern about questions of health, nutrition (campaigns to reduce obesity and excess weight, cardiovascular diseases) and sustainable development (respect for the environment, preservation of agricultural land and resources, fair trade, local development, etc.). These new forms of pressure have been exerted at state level (e.g. launch in France in 2001 of the National Nutrition and Health Programme), as well as by public bodies and NGOs.

This same period has also witnessed the emergence of a new type of consumer dubbed the "alter-consumer" with new requirements, and gradually coming to represent an increasingly important market segment. Under the banner "healthy eating", consumers attach increasing importance to the contents of labels and actively seek out norms and labels guaranteeing the "ethical" nature and quality of products. These "consum'actors" are also interested in the origin of the products they buy, and are increasingly aware of their role in the supply chain (from producer to final consumer).

Consequently, sustainable consumption takes a number of different guises in the market, with the notions of sustainable commerce (a commercial system unharmful to the environment), fair trade (ensuring that producers in developing countries receive prices that allow them a decent standard of living and the possibility of developing), ethical commerce (the institution of a production system that respects basic worker rights), solidarity trade (support through one's purchases for a solidarity organisation), and organic and healthy produce. 
CSR has thus partly modified the expectations of a certain group of consumers (emergence of new segments, incorporation of ethical criteria, etc.), prompting actors to redefine their strategy and market position.

Market leaders have responded to this new development uniformly by adopting the same strategy, which consists of embracing innovation in terms of techniques (scientific norms) in a bid to create barriers to entry through the introduction of heavy investment strategies at their production facilities (reduction of production costs), health aims (reduction of hydrogenated products, etc.), marketing (refocusing on key brands) and organic products. "In order to differentiate our products, we have placed the focus on quality", noted a manager with Lu. "Innovation constitutes the key axis of development for Lu", indicated a spokesperson for the group, for whom new products represent $10 \%$ of annual turnover.

Major companies are thus developing new generations of products based on this "health" approach. The aim is to present new products as conferring a protective effect against disease: reduced sugar content, lower fat content and use of "bioactive" ingredients to improve gastrointestinal health, enrichment with fruit, cereals, and fibre, fortification with vitamins, and so on.

\subsection{The "Michel et Augustin" Strategy}

"Michel et Augustin" was created in 2004 by Michel de Rovira (MdR) and Augustin Paluel-Marmont (AP-M) as a 50/50 partnership with a starting capital of 15000 euros. The company was initially positioned in the biscuit market (in early 2000, AP-M decided to take a professional bakery-pastry chef diploma, prompted by a long-standing passion for this area), a market which, as we have seen, is "saturated", in decline and dominated by extremely powerful international actors.

The original business project was inspired by Ben \& Jerry. On discovering the latter brand, AP-M noted that within the biscuit sector: "no existing brands stood out and spoke to me. Communication consisted solely of so many fabricated tales". Furthermore, the discourse of the major brands is often austere, and even according to the directors, untruthful. "I feel no affection for supermarket products and I was shocked by their outright lies. Nutella's claims that eating their product is necessary for health are an insult to the customer's intelligence. Nutella may taste good, but the only thing it really helps the body to do is to put on weight" (AP-M).

The company creators were also inspired by Richard Branson, whom they see as the incarnation of "joie de vivre, energy, overriding optimism and sharing”. (AP-M)

Finally, they note that it is often very difficult to decipher the composition of products, which frequently contain ingredients not in normal everyday use: "You need a Nobel Prize in chemistry to understand the list of ingredients used in what you buy and eat". "I do a lot of pastry cooking but I've never used hydrogenated palm oil". (AP-M)

Based on these findings, they decided to launch a brand that would create a new relationship with stakeholders, and particularly customers, based on values such as "pleasure, a positive outlook, insistence on the value of humans, sharing and transparency" (AP-M). As such, the company directors' approach to the market has been guided by a positive view of the new context created by CSR (authenticity, pleasure, sharing), which they refuse to see as restrictive and institutionalised, in contrast with how it is viewed by the two leading companies in the sector (norms, labels, procedures, etc.). In this regard, Michel et Augustin has rejected the path of certification: "Our port of entry is not through organic certification. We simply select the best possible ingredients, produced for the most part in France".

The company decided to enter the biscuit segment, which it associates with a positive and convivial ethos: "It is a simple matter to share biscuits with others - anyone can do this in their own home. Biscuits represent a way of sharing one's state of mind" (AP-M).

4.2.1 Relations with Consumers: A Transparent and Authentic Relationship Based upon Pleasure and Sharing

The company's approach to the market is dominated by particular values:

(1) Personalisation is embodied in the company name (the first names of the two creators), the company logo (the faces of the two directors) and the packaging, on which the directors recount facets of their private lives: "Michel has 2 green plants, a bicycle and not much hair".

This personalisation is based upon a particular finding: "People have more trust in other people than in companies. My main concern is that they should naturally feel that the product is good because it is made by Michel et Augustin, and that it has been personally endorsed by Michel and Augustin” (MdR). 
(2) Proximity is associated with the accessibility of the directors and of the company. For example, the two directors are happy to give out their personal telephone numbers. Similarly, on the first Thursday of each month, the "Bananeraie" (the company's head office in Boulogne Billancourt, just outside Paris) opens its doors to its customers, offers a tasting of its latest products, and notes all comments passed there. As a general rule, the company welcomes interactivity between its stakeholders, including its customers, and invites them to become involved with the life of the company. This is emphasised by the following message found on the company's biscuits: "Ours is a tasty and healthy adventure, full of energy and crazy projects, and above all it is a human adventure. And it involves you, the deliverer, shop owner, or member of the tribe of "taste upstarts": everyone has their word to say about taking the adventure forward."

The open-door events are very carefully organised in terms of numbers of participants (sometimes up to 400).

"Our premises are organised into a tasting stand, a theme-based bar (CV stand, Aventure stand, etc.) and workshops, enabling us to enjoy a quality and privileged contact with everyone involved". (AP-M)

(3) Finally, attachment to transparency and truth are embodied in the liberal diffusion of the composition of products and the recipes used, as well as the complete absence of any false claims, particularly regarding health. As the directors themselves have said: "Initially, it was just the first names of friends [...] explaining their own feelings as consumers. We'd had enough of being manipulated by the brands and of being unable to understand the ingredients used in food products sold in the major retail stores. We began with a sincere wish to embark upon a human adventure of taste with our consumers".

Internet, via the company website and blog, also forms an important mode of communication, with comments on products, details of sales outlets, brand co-management, videos and photos showing employees, presentation of the tribe, a view behind the scenes of a marketing operation, participation in staff recruitment, etc. In addition, a monthly newsletter, "Le bananier", gives details of the various events involving the brand and has 50000 subscribers. The company also has 31000 friends on Facebook, placing it far ahead of the leaders in the food sector (by comparison, Lu has only 2300 friends): "Our policy is to share the day-to-day life of the brand with the entire tribe". (AP-M)

All of these combined actions give each individual consumer the feeling of playing a role in the company and create an authentic relationship of trust between the brand and its customers.

Pleasure is another indicator of the company's success. While customers are torn between feelings of blame and anxiety concerning their eating habits on the one hand and feelings of pleasure on the other, Michel et Augustin have managed to reconcile these two aspects through a departure from the traditional austere discourse.

The position of Michel et Augustin is accompanied by an unusual communication policy based upon humour, fun, "buzz" (comic videos, events, street marketing, etc.), conviviality and exchange. This communication strategy aims at creating immediate complicity with customers.

This position is also embodied by the company's atypical packaging:

- Graphics (lively vibrant colours, avoidance of sophistication, childlike drawings such as the cow, the table and chalk, and the flower).

- Product names with a highly personal touch: "petits sablés ronds and bons” (Note 3) and so on”.

- The logo created by Michel et Augustin shows caricatures of the two directors.

- The slogan: «les trublions du goût» (Note 4).

- The humour found on the packaging is far removed from the standard discourse routinely printed on packets of biscuits: "Did you know that eating these "petits sablés ronds and bon" [...] will help you lose weight, boost your energy levels and strengthen your bones? You see, our nutritionists in their gleaming white lab coats, have worked hand-in-hand with NASA to develop ... Stop! That's enough of this nonsense!”.

- Use of very familiar language and enjoinders with exclamation marks: "Get cooking and let's speak!: Over to you! Here's to life and friends!"

- Imaginative use of the packaging (words hidden at the back of boxes, jokes printed on boxes, use of small arrows to comment on certain points, etc.)

The aim is to create "Products that speak to consumers and raise a smile in supermarkets" (MdR). The company wished to break with the boredom and monotony of traditional packaging by eradicating a formal and 
distant approach. Their goal is to create an authentic relationship with consumers through their product packaging.

Text Box 1. Decoding the relationship between Michel et Augustin and their customers

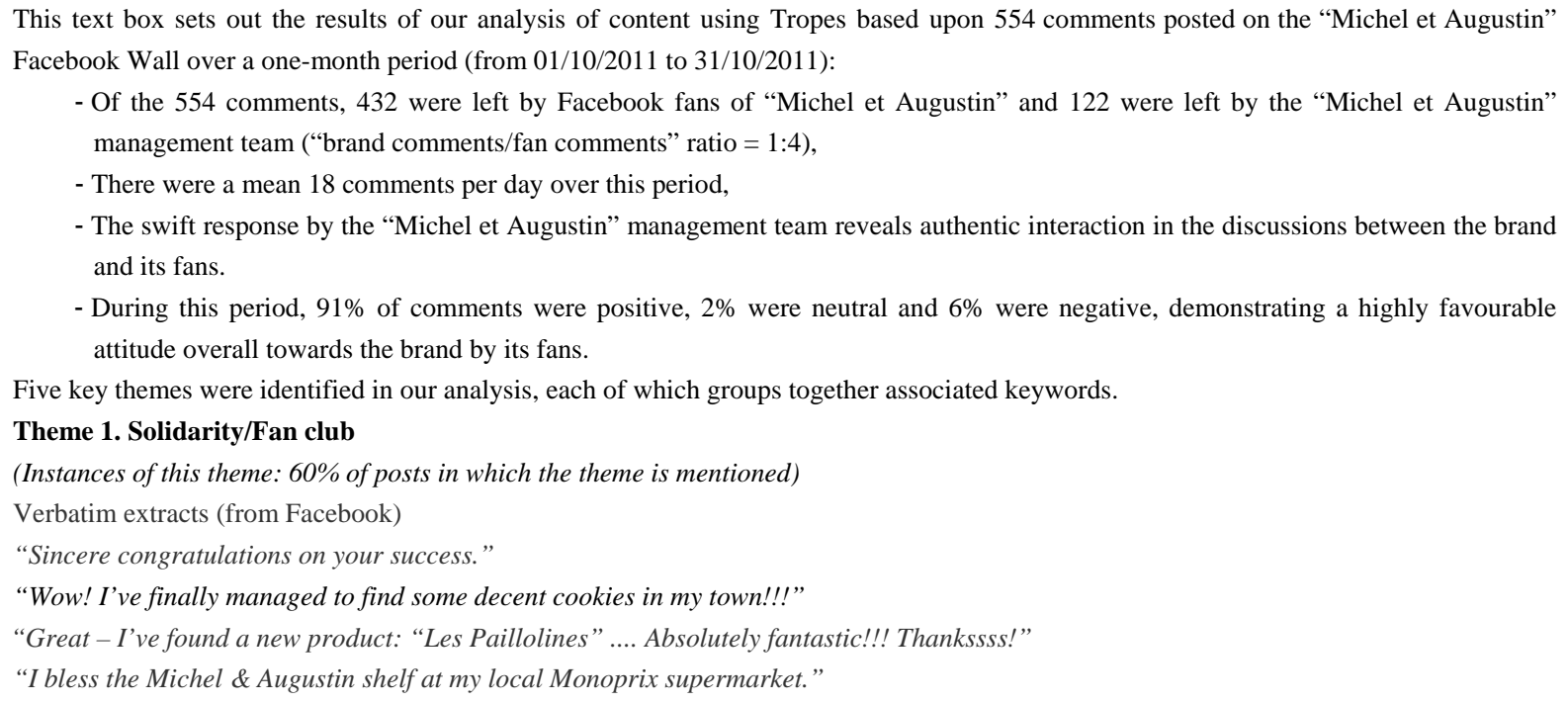

- The swift response by the "Michel et Augustin” management team reveals authentic interaction in the discussions between the brand and its fans.

- During this period, $91 \%$ of comments were positive, $2 \%$ were neutral and $6 \%$ were negative, demonstrating a highly favourable attitude overall towards the brand by its fans.

Five key themes were identified in our analysis, each of which groups together associated keywords.

Theme 1. Solidarity/Fan club

(Instances of this theme: $60 \%$ of posts in which the theme is mentioned)

Verbatim extracts (from Facebook)

"Sincere congratulations on your success."

"Wow! I’ve finally managed to find some decent cookies in my town!!!”

"Great - I’ve found a new product: "Les Paillolines”.... Absolutely fantastic!!! Thankssss!”

"I bless the Michel \& Augustin shelf at my local Monoprix supermarket."

Theme 2. Humour, self-deprecation/ Joie de vivre (38\%)

"Have Lu or Danone ever put a smile on your face while you were out at the shops?"

"How can I explain ... it's not that it's good, it's sweet and melts in your mouth; every mouthful is a pure delight and makes you think: isn't life just great at times like this!!!”

"happiness, happiness, just happiness!"

Theme 3. Pleasure/ Taste/Attitude to life (36\%)

"Michel \& Augustin may not be the most innovantive brand in the last hundred years but they've created some great desserts that go some way beyond the standard fare from the major brands."

Theme 4. Tribe (29\%)

"Hail to the trine! I'll have to get myself back to Montauban again to raise a taste rumpus with you all!"

"Hello all you fellow taste upstarts!"

Theme 5. Personalised approach (20\%)

"What news of Augustin?"

"Poor Augustin!! It’s such a shame for him!!”

Michel et Augustin thus decided to adopt a different position to that of their competitors: very tasty products with high-quality, natural ingredients (using butter but not oil, with no added colouring agents, etc.) and without preservatives, though at a higher price (between 2 and 6 euros). They have in fact opted to play the "healthy" or ecologically responsible "organic" card, catering for the hedonistic "food as pleasure" market, with the accent firmly placed on pleasurable eating and the taste of "good things", without any moralising or reproachful discourse, and with the emphasis firmly on conviviality. The company thus seeks to "Bring back the taste of biscuits as they were baked by our grandmothers, using only the best ingredients and with no additives or preservatives". The company assumes that the ingredients used in their products are readily available household items, in contrast with other brands, whose ingredients are barely intelligible to customers.

\subsubsection{Relations with Suppliers and Distributors}

The company makes much of local supply and manufacture in France rather than insisting on fair trade: "You can't really call our operation fair trade since were not really in a position of a developed country purchasing from less developed economies. What we are seeking is rather a lasting relationship involving long-term collaboration with French producers and securing long-term supply of milk for our products." 
It is also consciously turned towards a durable consumer base, appealing to the taste and curiosity of consumers for high-quality products rather than resorting to organic labelling. "I don't use organic milk because this would mean importing it from East Germany. The milk I use comes from Gap in the southern French Alps, which also has the advantage of proximity since Gap is only 2 hours away from my production plant. Also, we are not an organic producer, since as consumers, we ourselves don't eat organic food.” However, the company is sensitive to environmental issues: "We are sensitive to environmental constraints and we are testing packaging involving lower $\mathrm{CO}_{2}$ emissions."

Suppliers are considered partners in the company's development in the same way as clients and consumers. Here, the notion of confidence is a priority consideration and the company is seeking to maintain durable win-win relations with suppliers by insisting on proximity and interaction: "We have a contract in place with our suppliers that guarantees stable prices for farmers, even in periods of financial crisis." "Our relationship with farmers is not simply commercial." "There are many people with whom we do not have a contract, in most cases because our dealings are based on mutual confidence." "A relationship based on confidence implies presence, and in this respect, we spent a good deal of time at our suppliers' production facilities." (AP-M)

Similarly, distributors are also considered by Michel et Augustin as members of the tribe, and they too have "their word to say about taking the adventure forward":

"One of our customers gave us the idea of launching our floating island products. In reality, the company strategy is an ongoing creative back-and-forth process involving a mixture of contributions from inside and outside the company. It was also a customer who encouraged us to bring out a range of Christmas products towards the end of 2012."

\subsubsection{Relations with Collaborators}

The company's management style is democratic and frequently informal.

The company favours a direct approach: "Most of the time, we receive e-mails from our collaborators who simply want to reassure themselves by informing us of a problem. I send them an automatic response in the form of a parody, which goes something like: your e-mail has been automatically destroyed; if you have any urgent questions, please come and see me personally instead."

The company favours a natural and continuous decision-making process: "There are no major committee sessions at which decisions are taken. This is due mainly to the fact that we don't spend a lot of money and no major investments are required. Everything is done with common sense, enthusiasm and passion."(A-PM)

However, one day (Monday) is devoted to resolving pressing issues:

"Rather than calling numerous meetings, which can be a crippling waste of time, we prefer to tackle questions at a single sitting, when they require an immediate response." "This system also reduces the amount of time needed to deal with e-mails. We each receive 100 or so e-mails a day; rather than answer each one individually, we deal with the issues they raise at our Monday meetings."

The website places the accent on members of the "tribe" and highlights each employee personally as well as their respective contribution: "We met Severine at a pic nic one summer and she conjured up the very first package illustration for ours biscuits. Thank you Severine." (Michel et Augustin website)

Michel et Augustin also attach a great deal of importance to the recruitment process.

"I want the recruitment process to be something unique, a really rewarding experience for candidates". As regards recruitment criteria, in addition to the essential technical skills, the company seeks positive personalities:

"We are looking for co-workers who are happy in their lives, well adjusted, creative, innovative and enthusiastic, with plenty of common sense and energy".

To this end, the company seeks passionately interested partners who are highly motivated and who view their activity not as work but rather as participation in the shared adventure.

The selection methods are in keeping with this aim.

"Naturally there are interviews and role playing tests. We attach great importance to the lunch at which the candidate interacts with all the company's collaborators."

"For example, for one prospective sales manager, we recreated a shop at the Bananeraie. Some of our employees played the role of shopkeepers and we were able to see how the candidate behaved, how he reacted to certain situations with which he was confronted." 
"In reality, recruitment decisions are made collectively as a team based on consensus between all the employees."

Regarding the policy of motivation of employees, Michel et Augustin place the emphasis on attaining joint objectives and collective rewards that are implicit (collective events) rather than explicit (remuneration, promotion).

"To celebrate our record sales figures for the month of May 2011, we organised a large Bellota ham party at the Bananeraie."

"We all went off on a two-day trip to Morocco. There are many smaller events that, while not necessarily sumptuous, contribute greatly to group motivation and cohesion.”

On the theme of career management policy, there are no career plans for employees given the company's size and corporate culture. Michel et Augustin focused primarily on working together to advance their employees' careers and on the importance of employees being intrapreneurs :

"Our employees have to be intrapreneurs. Since the company is expanding rapidly, there are many extremely interesting subjects to be tackled and it is up to the individual employee to respond accordingly."

Text Box 2. Factors ensuring staff motivation and loyalty to the company

Our content analysis allowed us to identify a number of key phrases associated by staff with Michel \& Augustin indicative of a very special
relationship between the company and its employees: (in decreasing order of frequency) adventure, sharing, transparency, pleasure/fun,
initiative/autonomy, positive outlook and proximity.
Sources of attractiveness
"A great deal is left to the initiative and responsibility of the individual. Each employee is an entrepreneur personally shouldering part of the
project."
"The entire adventure is based on the principle of sharing with a desire for complete transparency towards those following our steps in the
various media, whether customers or partners".
"I joined the company because of its emphasis on fun and its positive outlook; everything about it is good-humoured."
Sources of loyalty
"It is up to employees to grow with the adventure and manage an entrepreneurial project associated with Michel \& Augustin."
"At Michel \& Augustin, there is no stifling administration or bureaucracy, and no inertia; everything moves along very quickly, which is
extremely agreeable."
"We are continually updated about developments within the company; everything is transparent and you really get the impression of being
involved in a joint adventure, in which everyone has an important role to play."
"I don't see myself as an employee, but more as a member of the company, fully involved in the adventure."

\subsubsection{Relations with Society}

The involvement of the directors in humanitarian and social projects are considered as personal undertakings, and are not accompanied by ostentatious press releases. These projects are based on "values of solidarity and sharing" held by the two directors. They are linked with a certain degree of indifference to money. "We have no ambition to race around in Porsches, and the company we are building is designed to serve those values in which we personally believe." "Our aim is to develop the company while remaining faithful to our convictions." "Money in itself is of little interest to us other than what we can do with it in terms of redistribution."

While the company is sensitive to the notion of a citizen company, it favours pragmatic projects on a human scale dealing with "entrepreneurship, solidarity and sport." "The first thing I did as soon as we were able was for example to bring on board Martin, who is a really fantastic guy, who does lots of little jobs for us around town, and who happens to be mentally handicapped."

"We hire out our meeting room on a daily basis; it is used by many people and we donate the resulting income to associations, and we welcome handicapped children.”

"We are fighting many small battles each day on a modest scale, and we don't have any major battles on which we focus all our attention and energy; we are just normal French people sensitive to a variety of issues."

Thanks to its novel position and its method of creating special relationships with its stakeholders, Michel et Augustin has increased its turnover 60-fold in 5 years (from 500000 euros in 2006 to 30 million euros in 2011). 
Using the analytical table presented in the first section, we shall analyse the reasons for this success (see next section).

\section{Discussion and Conclusion}

The case we have presented here highlights a number of approaches and practices that diverge sharply from the general norms within this sector. It shows how a small company (in this case a new company) can break the established mould and follow an innovative strategy based upon specific key factors for success as well as an original method. Michel et Augustin has in fact managed to take advantage of the norms imposed by CSR to develop its own growth model. Faced with new barriers to entry loaded in favour of large companies already present in the sector (costs of R\&D, social and societal communication, food safety regulations, etc.), Michel et Augustin decided to circumvent this obstacle by changing the way in which the issue of CSR is perceived and managed within its own development policy. Instead of focusing on the technical aspects (selection, rigour, control and monitoring) and the economic issues (resource management and optimisation), the company decided to seek new advantages through an innovative model of relationships with all of its stakeholders. It has adopted a veritable "shareholder" strategy based on transparency, spontaneity and trust in order to turn its various stakeholders into the principal actors and contributors within this entrepreneurial adventure.

Unable to compete in terms of dimensions (company size, sales volume, turnover, R\&D budget, etc.) or of scientific aspects (dietetics, health, nutrition, etc.), Michel et Augustin focused instead on building up a collective adventure that brings together clients, staff, distributors and other stakeholders under the banner of jointly held values such as pleasure, truthfulness and sharing. The aim is no longer simply to "do good" for customers but rather to "do good for everyone", by openly embracing certain tendencies ostensibly mocked or derided, such as overindulgence, a childish outlook, mixing up different styles (the notion of the tribe extends to the company hierarchy, staff and customers) and refusing to indulge in standard institutional communication ploys designed to satisfy shareholders. Thus, Michel et Augustin is no longer viewed as a simple company developing commercial relations with its environment, but as a portal into a new tribal world in which one embraces shared values based on "taking pleasure together" via certain products and events. As illustrated in Table 2, this approach has allowed Michel et Augustin to adopt an innovative stance and clearly differentiate itself from the leaders in the biscuit market.

Table 2. Comparative analysis of how CSR is perceived by actors in the biscuits sector

\begin{tabular}{|c|c|c|}
\hline & Leaders in the sector (Nestlé, Danone, Kraft) & Michel et Augustin \\
\hline Purpose & A means of reinforcing barriers to entry & A means of entering the market \\
\hline Stake & New norm requiring compliance (new orthodoxy) & An opportunity to upset the rules of competition \\
\hline Key factors for success & $\begin{array}{l}\text { Extent of mobilisable resources (effects of size, } \\
\text { power in the market) }\end{array}$ & Adaptation - Imagination -Singularity (innovation) \\
\hline Managerial response & $\begin{array}{l}\text { - Interpretation as part of the existing paradigm } \\
\text { - Strengthening and improvement of existing skills }\end{array}$ & $\begin{array}{l}\text { - Creation or construction of a new paradigm } \\
\text { - Exploration of new and untested activities }\end{array}$ \\
\hline $\begin{array}{l}\text { Possible types of innovation } \\
\text { engendered }^{*}\end{array}$ & "Incremental” or “major” competitive innovation & "Radical" or "strategic" innovation \\
\hline
\end{tabular}

Note: ${ }^{*}$ The classification of C. Markides and P. Geroskiqui incorporates four types of innovation combining two factors: the impact of innovation on the skills and staff of established companies and the impact of innovation on consumer habits and behaviour.

The CRS-compatible strategy of Michel \& Augustin differs from that of its competitors in terms of its approach to its stakeholders. The company is seeking to transform its staff, partners (suppliers, investors, etc.) and its clients into actors within the same tribe and sharing the same vision and the same concerns (see Table 3).

Its aim is to break down the classic employee/company, supplier/company and consumer/company barriers.

The case we have studied consequently calls into question certain preconceived ideas about the relationship between company size and performance, which, according to many studies, tends to favour large companies in highly competitive traditional sectors. It shows that a different approach to CSR based upon a new philosophy of relationships, in particular with stakeholders, and a new interpretation of proximity (application of CSR principles to the local community, e.g. the opportunity for consumers to visit the company headquarters monthly in order to share and build together) could constitute a tool to provide added value for SMEs (Lepoutre \& Heene, 2006; Spence, 2007). More particularly, this article offers a new approach to the link between CSR and innovation as a break with the past by viewing CSR as an opportunity for a company to change the rules of competition (proactive strategy) rather than simply as a corporate constraint (adaptative strategy). 
Table 3. Comparison of company approach to stakeholders

\begin{tabular}{|c|c|c|}
\hline New requirements of CSR & Strategy of leaders & Michel et Augustin \\
\hline \multicolumn{3}{|l|}{ Consumers } \\
\hline $\begin{array}{l}\text { Seek information about the } \\
\text { composition of products }\end{array}$ & $\begin{array}{l}\text { Organic labels used but a formula that is } \\
\text { either secret or technically unaccessible }\end{array}$ & $\begin{array}{l}\text { Transparency, clearly stated formulas, products that anyone } \\
\text { could cook }\end{array}$ \\
\hline Manufacturing conditions & No information & Traditional method \\
\hline Health, nutrition & Organic sector & The most natural and healthy products possible \\
\hline $\begin{array}{l}\text { Detailed history of the product } \\
\text { they are buying }\end{array}$ & $\begin{array}{l}\text { Organic sources, } R \& D \text { investment, } \\
\text { innovative products }\end{array}$ & $\begin{array}{l}\text { Personalisation of brand, authentic friendship between } \\
\text { Michel and Augustin }\end{array}$ \\
\hline Suppliers and distributors & $\begin{array}{l}\text { Fair trade } \\
\text { CSR norms } \\
\text { Marked formalisation } \\
\text { Classic subcontractor relations } \\
\end{array}$ & $\begin{array}{l}\text { Selection of French suppliers with lasting relations } \\
\text { Relations based on trust and occasionally informal (no } \\
\text { contracts) }\end{array}$ \\
\hline Employees & $\begin{array}{l}\text { Staff } \\
\text { Corporate culture (innovation, client, etc.) } \\
\text { Managerial charts } \\
\text { Bureaucratic } \\
\end{array}$ & $\begin{array}{l}\text { Members of the tribe (collective adventure) } \\
\text { Democratic management (sense of initiative, etc.) } \\
\text { Pleasure, proactive approach, } \\
\text { transparency, proximity }\end{array}$ \\
\hline Company & $\begin{array}{l}\text { CSR commitments trumpeted in media, } \\
\text { Programme of far-reaching CSR actions }\end{array}$ & $\begin{array}{l}\text { Private and pragmatic commitments on a case-by-case basis } \\
\text { CSR based on proximity } \\
\text { Ethics, personal philosophy }\end{array}$ \\
\hline
\end{tabular}

\section{References}

Andrew, S., Salamonson, Y., \& Halcomb, E. J. (2008). Integrating mixed methods data analysis using NVivo: An example examining attrition and persistence of nursing students. International Journal of Multiple Research Approaches, 2, 36-43. http://dx.doi.org/10.5172/mra.455.2.1.36

Baretto, I., \& Baden-Fuller, C. (2006). To Conform or to Perform? Mimetic Behaviour, Legitimacy-Based Groups and Performance Consequences. Journal of Management Studies, 43(7), 1559-1581. http://dx.doi.org/10.1111/j.1467-6486.2006.00620.x

Blombäck, A., \& Wigren, C. (2009). Challenging the importance of size as determinant for CSR activities. Management of Environmental Quality: An International Journal, 20(3), 255-270. http://dx.doi.org/10.1108/14777830910950658

Brabet, J. (2009). Débats sur la responsabilité sociale de l'entreprise. In B. Pras. (Ed.), Management: Tensions d'aujourd'hui. Vuibert. Collection FNEGE.

Capron, M., \& Quairel-Lanoizelée, F. (2007). La responsabilité sociale d'entreprise. Coll. Repères, eds La Découverte, p. 122.

Caroll, A. (1999). Corporate Social Responsibility. Evolution of a Definitional Construct. Business and Society, 38(3), 268-295. http://dx.doi.org/10.1177/000765039903800303

Castka, P., Balzarova, M. A., Bamber, C. J., \& Sharp, J. M. (2004). How can SMEs effectively implement CSR agenda? A UK case study perspective. Corporate Social Responsibility and Environmental Management, 11, 140-9. http://dx.doi.org/10.1002/csr.60

Christensen, C., Johnson, M., \& Rigby, D. (2002). Foundations for Growth, How to identify and build Disruptive New Businesses. Sloan Management Review, 43(22), 22-31.

Ciliberti, F., Pontrandolfo, P., \& Scozzi, B. (2008). Investigation corporate social responsibility in Supply chains: a SME perspective. Journal of cleaner production, 16, 1579-1588. http://dx.doi.org/10.1016/j.jclepro.2008.04.016

De Bakker, F., Groenewegen, P., \& Den Hond, F. (2005). An analysis of 30 years of research and Theory on CSR/CSP. Business and Society, 44(3), 283-317. http://dx.doi.org/10.1177/0007650305278086 
Di Maggio, P., \& Powell, W. (1983). The Iron Cage Revisited: Institutional Isomorphism and Collective Rationality in Organizational Fields. American Sociological Review, 48(2), 147-160. http://dx.doi.org/10.2307/2095101

Di Maggio, P., \& Powell, W. (1991). The new institutionalism in organizational analysis. Chicago,IL: University of Chicago Press.

Dogson, M., \& Rothwell, R. (1991). Technology Strategies in Small Firms. Journal of General Management, 17(1), 45-55.

Fitjar, R. D. (Jan 2011). Little big firms? Corporate social responsibility in small businesses that do not Compete against big ones. Business Ethics. A European Review, 20(1), 30-44. http://dx.doi.org/10.1111/j.1467-8608.2010.01610.x

Foray, D., \& Mowery, C. (1988). Growth in Small and Medium-Sized Enterprises. Cambridge University, Centre for Business Research.

Friedman, M. (1970). The social responsibility of business is to increase its profits. The New York Times Magazine, 13, 33. http://www.umich.edu/ thecore/doc/Friedman.pdf

Graafland, J., Van De Ven, B., \& Stoffele, N. (2003). Strategies and instruments for organizing CSR By small and large businesses in the Netherlands. Journal of Business Ethics, 47(1), 45-60. http://dx.doi.org/10.1023/A:1026240912016

Hoivik, H. von W., \& Shankar, D. (2011). How Can SMEs in a Cluster Respond to Global Demands for Corporate Responsibility? Journal of Business Ethics, 101(2), 175-195. http://dx.doi.org/10.1007/s10551-010-0708-6

Husted, B. W., \& Allen, D. B. (2007). Strategic corporate social responsibility and value creation among Large firms. Long Range Planning, 40, 594-610. http://dx.doi.org/10.1016/j.lrp.2007.07.001

Jenkins, H. (2004). A critique of conventional CSR theory: an SME perspective. Journal of general Management, 29(4).

Jenkins, H. (2006). Small Business champions for corporate social responsibility. Journal of Business Ethics, 67(3), 241-56. http://dx.doi.org/10.1007/s10551-006-9182-6

Karsenti, Th., \& Savoie-Zajc, L. (2000). Introduction à la recherche en éducation. Sherbrooke: Editions du CRP.

Lepoutre, J., \& Heene, A. (2006). Investigating the impact of firm size on small business social Responsibility: a critical review. Journal of Business Ethics, 67(3), 257-73. http://dx.doi.org/10.1007/s10551-006-9183-5

Longenecker, J. G., Moore, C. W., Petty, J. W., Palich, L. E., \& Mc Kinney, J. A. (2006). Ethicalk attitudes in Small businesses and large corporations: theory and empirical findings from a tracking study spanning three decades. Journal of Small Business Management, 44(2), 167-183. http://dx.doi.org/10.1111/j.1540-627X.2006.00162.x

Martinet, A. C., \& Reynaud, E. (2004). Entreprise durable, finance et stratégie. Revue Française de Gestion, 30(152), 121-136.

Meyer et Sott. (1986). Even dwarfs started small: liabilities of size and age and their strategic Implications. In B. M. Staw \& L. L. Cummings (Eds.), Research in organizational behavior, 8.

Miles, M. B., \& Huberman, M. A. (2003). Analyse des données qualitatives (2nd ed.). Paris: De Boeck.

Moore, S. B., \& Manring, S. L. (2009). Strategy development in small and medium sized enterprises for sustainability and increased value creation. Journal of cleaner production, 17, 276-282. http://dx.doi.org/10.1016/j.jclepro.2008.06.004

Morsing, M., \& Perrini, F. (2009). CSR in SMEs: Do SMEs matter for the CSR agenda. Business Ethics: an European Review, 18(1). http://dx.doi.org/10.1111/j.1467-8608.2009.01544.x

Murillo, D., \& Lozano, J. (2006). SMEs and CSR: an approach to CSR in their own words. Journal of Business Ethics, 67(3), 227-40. http://dx.doi.org/10.1007/s10551-006-9181-7

Penrose, E. T. (1959). The theory of the growth of the firm. Oxford: Basil Blackwell.

Perrini, F. (2006). SMEs and CSR theory: evidence and implications from an Italian perspective. Journal of Business Ethics, 67(3), 305-16. http://dx.doi.org/10.1007/s10551-006-9186-2 
Perry, P., \& Towers, N. (2009). Determining the antecedents for a strategy of CSR by small and Medium sized enterprises in the UK fashion apparel industry. Journal of retailing and consumer Services, 16(5), 377-385. http://dx.doi.org/10.1016/j.jretconser.2009.05.003

Pourtois, J-P., \& Desmet, H. (1997). Epistémologie et instrumentation en sciences humaines (2nd ed.). Sprimont: Mardaga Editeur.

Reynaud, E. (2006). Le développement durable au cœur de l'entreprise. Pour une approche transverse du développement durable. Dunod, p. 256.

Ryan, G. W., \& Bernard, H. R. (2003). Data management and analysis methods. In Denzin, N. K., \& Lincoln, Y. S., (Eds), Collecting and Interpreting Qualitative Materials (2nd ed.). Thousand Oaks, CA: Sage Publications.

Scherer, F. M. (1970). Industrial market structure and economic performance. Rand McNally college Publishing Company.

Seale, C. (1999). The Quality of Qualitative Research (p.214). London : Sage.

Seuring, S., \& Muller, M. (2008). From a literature review to a conceptual framework for sustainable Chain

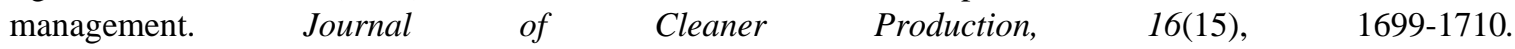
http://dx.doi.org/10.1016/j.jclepro.2008.04.020

Spence, L. J. (1999). Does Size Matter? The State of Art in Small Business Ethics. Business Ethics: A European Review, 8(3), 163-174. http://dx.doi.org/10.1111/1467-8608.00144

Spence, L. J. (2007). CSR and small business in a European policy context: the five "C"s of CSR and small business research agenda 2007. Business and Society Review, 112(4), 533-52. http://dx.doi.org/10.1111/j.1467-8594.2007.00308.x

Valiorgue, B. (2005). Acteurs non décideurs et processus de formation de la responsabilité sociale de l'entreprise. Journée Développement Durable de l'Association Internationale de Management Stratégique, IAE Aix en Provence, May 2005.

Wood, D. J. (1991). Corporate social performance revisited. Academy of Management Review, 16, 691-718. http://dx.doi.org/10.5465/AMR.1991.4279616

Worthington, I., Ram, M., \& Jones, T. (2006). Exploring corporate social responsibility in the U.K. Asian small $\begin{array}{lllll}\text { business community. Journal of Business Ethics, 67(2), } & \text { 201-17. }\end{array}$ http://dx.doi.org/10.1007/s10551-006-9024-6

Yin, R. (2003). Case Study Research, Design and Methods. 3ème edition, Applied Social Research Methods Series, 5.

\section{Notes}

Note 1. Management, “40 astuces pour gagner du temps", February 2011; Le Figaro Economie, "Michel et Augustin, prêt à ouvrir son capital”, January 2011; Les Echos, “A la conquête du client”, 19 April 2011; Les Echos, "Michel et Augustin, une recette qui marche”, 19 July 2010; Dynamique entrepreneuriale, "Le moral? Une question d'équilibre”, April 2010; Le Parisien, "Et maintenant, une boutique Michel et Augustin”, 30 January 2010; Marketing, "L’homme marketing de l'année 2010”, March 2010; Challenges, "Un profil citoyen pour les rois du web”, 8 July 2010.; LSA, “Palmares de l’innovation”, 18 February 2010; Le Point, “Michel et Augustin, les insolents”, November 2010; Management, "Apprenez à vaincre votre timidité”, July-August 2009; Capital, “Comment faire de la pub sans budget de pub?”, March 2008; FHM, “Des patrons pas comme les autres”, October 2008; Ria, "Petites entreprises, cap sur l'audace”, July 2008; Libération, "Michel et Augustin, yaourts and gateaux parfum culot”, 24 September 2006.

Note 2. All posts submitted by customers were collected in a database for processing in Tropes V8.

Note 3. Tasty small rond biscuits.

Note 4. "the taste upstarts". 